\title{
'Danaides Myth' in Greek Political and Strategic Culture after the Coup and the State Regime (Metapolitefsi) (1974)
}

\author{
Nicolas Papanastasopoulos* \\ Postdoctoral Fellow, Panteion University, Athens, Greece \\ *Corresponding Author: Nicolas Papanastasopoulos, Postdoctoral Fellow, Panteion University, \\ Athens, Greece

\begin{abstract}
This article detects the relationship between the political and strategic culture through the case study of the example of the Greek state after the coup and the state regime in 1974. In other words, it focuses on the historical course of the Greek state and on those components that formed its political culture in interaction with the corresponding strategy. Emphasis is placed on Greeceafter the coup and the state regime in 1974, which demonstrates the dimension of Danaides Myth that governs their dialectical relationship.

As long as the political culture is atrocious, it will expose itself to the level of the strategy with negative results in the fields of operation of the political system, in particular the foreign and defense policy. The change or refinement of the Greek political culture is a sine qua non condition for the advancement of the strategic culture as a strategic doctrine that links the Greek state with its survival against the challenges it faces.
\end{abstract}

\section{INTRODUCTION}

This study combines analytical tools from the fields of Political Science, History, and International Politics, with a more reflective view. Initially, an analysis of the predominant terms is attempted, such as the political and strategic culture, in close connection with public policy, in the fields of foreign and defense policy. It presents the contemporary problem, as it results from the study of literature on the issues of the political and strategic culture.

Then, in a historical context, the identity of the modern Greek state is deciphered, through the institutional foundations that were attempted and questioned whether they expressed the Greek political anthropology. First and foremost, the hypothesis is that in the 19th century ('in whatever quantity') the political and strategic culture was identified, within the 'Great Idea'/ Megali Idea. Instead, the fission of their core comes in the 20th century, first with the National Conflict (which led to the Asia Minor Catastrophe), the emergence of a socialistic ideology and then with the Greek civil war, the dictatorship of the colonels and the tragedy of Cyprus.

Within such a framework, it is crucial to state that Greek structural context, after the coup and the state regime (metapolitefsi) (1974) was condemned to fail not so much in terms of institutional realization but due to the impregnation of a political culture with substantive content; a fact that had a direct reflection on the strategic culture of the country which, since the 1970s, faces Turkey's aggression.

After the historical demonstration, a comparison of the relationship between the political and strategic culture in other countries is attempted, including Israel, as a model of strategic culture, and to draw similar conclusions. The next section of the analysis concerns the role of leadership in the Greek political system after the coup and the state regime (metapolitefsi) (1974) period, where charismatic personalities alone were not capable of eliminating Danaides Myth's between the political and strategic culture in the period after the coup and the state regime in 1974.

It is clear that the methodological model followed is clearly influenced by the theory of constructivism, but also by neoclassical realism. This is because the homonymous perspective of constructivism, with its emphasis on ideology, history and culture as factors influencing foreign policy, has its own weight in the analysis. At the same time the approach of neoclassical realism, with a focus on the leadership, leads to the reflection of the current issue. 


\section{The Terms of the Problematic}

Danaides/Danaids Myth: in punishment for their crime (of killing their husbands) the Danaides in Hades were condemned to the endless task of filling with water a vessel which had no bottom. ${ }^{1}$

Public policy: Public policy is the process of selecting strategies and making choices. Public policy making includes several steps, such as agenda setting, policy formulation, policy adoptions, policy implementation. ${ }^{2}$

Foreign Policy: it deals with general objectives that guide the activities and relationships of one state in its interactions with other states. The development of foreign policy is influenced by domestic considerations, the policies or behaviour of other states, or plans to advance specific geopolitical designs. $^{3}$

Defence Policy: a system of projects or services intended to meet a public need or to respond to a threat. $^{4}$

Ideology: a set of beliefs, especially the political beliefs on which people, parties, or countries base their actions. ${ }^{5}$

Political Culture: it may be defined as the political psychology of a country or nation (or subgroup thereof). Political culture studies attempt to uncover deep-seated, long-held values characteristic of a society or a group. ${ }^{6}$

Strategic Culture: Strategic culture according to Snyder can be best defined as 'the sum of ideas, conditioned emotional responses, and patterns of habitual behaviour that members of a national strategic community share with regard to nuclear strategy. ${ }^{7}$

Strategic Doctrine: an overall statement of principles as to how forces are used at any stage. ${ }^{8}$

Constructivism: constructivism focuses on ideas of norms, the development of structures, the relationship between actors and said structures, as well as how identity influences actions and behavior among and between actors, as well as how norms themselves shape an actor's character. ${ }^{9}$

Neoclassical Realism: Neoclassical realism primarily aims at explaining the foreign policies of states by referring to both international and national (domestic) levels. ${ }^{10}$

Europeanization: Europeanization refers to: "Processes of (a) construction (b) diffusion and (c) institutionalisation of formal and informal rules, procedures, policy paradigms, styles, 'ways of doing things' and shared beliefs and norms which are first defined and consolidated in the making of EU decisions and then incorporated in the logic of domestic discourse, identities, political structures and public policies". ${ }^{11}$

Operational Code: The operational code can be defined as "a political leader's beliefs about the nature of politics and political conflict, his views regarding the extent to which historical developments can be shaped, and his notions of correct strategies and tactics" (George 1969). ${ }^{12}$

\section{THE Historical DiMENSION}

\subsection{The Course of the Greek State Since its Foundation and the Conceptual Assumption of Identity}

The historical course of Greek foreign policy in the last two centuries since the genesis of the Modern Greek state has been manifested in a number of ways (Svolopoulos 2000, 2007). While the time

\footnotetext{
${ }^{1}$ https://www.britannica.com/topic/Danaus-Greek-mythology\#ref234870

${ }^{2}$ https://www3.mruni.eu/ojs/public-policy-and-administration/article/view/2543

${ }^{3}$ https://www.britannica.com/topic/foreign-policy

${ }^{4}$ https://www.thefreedictionary.com/defence+policy

${ }^{5}$ https://www.collinsdictionary.com/dictionary/english/ideology

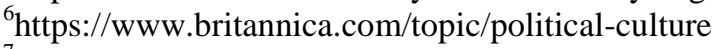

${ }^{7}$ www.lse.ac.uk/internationalRelations/.../Margaras.doc

${ }^{8} \mathrm{http}: / / \mathrm{www}$. gocatgo.com/texts/strat.tactics.doctrine.html

${ }^{9} \mathrm{http} / / /$ internationalrelations.org/constructivism_in_international_relations/

${ }^{10} \mathrm{http} / / / \mathrm{www} .0 x$ fordbibliographies.com/view/document/obo-9780199756223/obo-9780199756223-0187.xml

${ }^{11} \mathrm{https}$ ://europeanization.wordpress.com/2011/02/27/definitions-of-euroepanization/

${ }^{12} \mathrm{http} / / /$ socialscience.net/docs/operational_code_khrushchev.pdf
} 
transition from the 19th to the 20th century did not coincide with organic changes in the structure and operation of the international system, the continuity was not the same.

Observing the European environment, the sovereign presence of the Great Powers from 1815, as well as its centrifugal tendencies, is reflected through the timid and subsequent dynamic movements of national liberation of some (smaller) states. For Greece and its foreign policy, after independence, the national strategy aimed at completing the national rehabilitation. The rivalry within the field, the turbulent domestic political life has had a direct impact on shaping the identity of foreign policy.

Above all, however, the dominant national pursuit of defending the national sovereignty (from Turkish and Slavic dangers) was coupled with the 'protection' provided by the Great Powers. This coefficient, together with the geostrategic, population and economic data of the Modern Greek state, defined the performance of Greek foreign policy as stable.

The continuous dependence on foreign factors along with ideological (or obsessive) visions characterized the Greek foreign policy by the end of the 19th century. These irredentist tendencies that led to the formation of the Great Idea moved from the realm of the myth to the realistic treatment of conditions and opportunities.

At the dawn of the 20th century, the Great Powers' competition was staggering and found its appearance in crises - premonitions of a wider conflict. Greece's foreign policy in the years towards the end of the first half of the 20th century (1900-1945) is characterized by 'the search for dynamic integration into the system of international equilibrium' (Svolopoulos 2000, 2007). The political, strategic and economic vulnerability of the Modern Greek state interpreted the way for the realization of its national aspirations.

In the historical continuity, the Greek state has experienced situations ranging from the scale of significant diplomatic and military success to that of the disastrous failures due to variables dependent or independent of national targets. These developments, apart from the consequences on politics, economy and 'anthropogeography', had a structural and conceptual effect on the national and political identity of Greek society.

After the Asia Minor Catastrophe, the end of the two major wars of the century, the civil war and, in particular, the dictatorship of 21st April and the events of 1974 in Cyprus, its course is defined as a pendulum of the termination of the Cold War, the modern tendencies of globalization and the delicate balance with Turkey, especially in the Aegean.

Especially, in the years following the signing of the Treaty of Lausanne (1923), the safeguarding of the territorial integrity and independence of the national territory with the definitive abandonment of the Great Idea emerges as the main axis of Greek foreign policy. At the societal level, the exchange of populations between Greece and Turkey contributed to the creation of a fairly homogeneous national culture. This factor played a decisive role in the progressive consolidation of the identification of foreign policy issues with national survival ('national issues') by the population.

Due to history, geopolitics and the perception (or structural characteristic) of the 'weak and threatened state', coupled with the reduced bargaining power - in terms of political and economic power - and the 'ideological gap' created by the need to redefine the international identity of the country, the fundamental project of Greek foreign policy was created - namely, the international conduct on the basis of the supremacy of international law in transnational relations and the security created by the international institutions and, in particular, international organizations.

In this context, the implementation of the principles of the then League of Nations, the idealistic proposals for a federation of Europe or of the Balkans (there were proposals for a Greek-Turkish federation) that collapsed with the outburst of the Second World War, the country's tutelage and the burdensome ideological-pathological burden of the Greek civil war are pushing the country to join the UN (Also we see Greece's membership in the Organisation for Economic Cooperation and Development (1948), in the Council of Europe (1949) and in NATO (1952), but also the signing of the Association Agreement with the European Communities (1961)).Despite the Western orientation (a result of an ideological planetary polarization), the Greek foreign policy reveals characteristics of a political solidarity with the countries of the Arab world, while on the domestic political scene the shocks do not disappear culminating in the dictatorship of the colonels. The complete deviation from 
the principles and values of the UN and international organizations and the unequivocal conviction of the dictatorial regime with the American agent have led to the tragic events of Cyprus and the profound change in the strategy of the Greek foreign policy.

During the Greek state after the coup and the state regime in 1974, the Greek foreign policy, initially in a less realistic way, chooses Western Europe and is 'emancipated', mutatis mutandis, by the United States. However, the presence of charismatic leaders was catalyzed ('intoto'), resulting in a less institutionalized and more personal foreign policy (Papanastasopoulos, 2015).

What, however, is being put forward as a working hypothesis is that in the 19th century ('in whatever quantity') the political and strategic culture was identified, under the concept of the Great Idea/ Megali Idea. Instead, the fission of their core comes in the 20th century, first with the National Conflict/ EthnikosDihasmos (which led to the Asia Minor Catastrophe), the emergence of a socialistic ideology and then with the Greek civil war, the dictatorship of the colonels and the tragedy in Cyprus.

The dialectics of the 'distinct' identity of the Greek state in the stages from its birth to its territorial expansion and integration into international and European institutions and organizations is based on mythological, historical, nationalist and ideological, if not, ideological, explanatory forms. It has been argued (Ioakeimidis 2007) that 'the different answers to this fundamental question together with a series of other elements (folk culture, socio-economic composition, historical influences and tradition) form a historical set of different conceptual identities in terms of the identity, position and role of the modern Greek state'. In this process, four are the central conceptions 'regarding the identity, position, relationship and role of Greece in the world' (Ioakeimidis, 2007):

a) Greece as a European country based on the European vision. Apart from any of the manifestations we historically diagnose, the decisive point is the frost of the Cold War and the internal conflict.

In this context, two dominant tendencies are formulated: 'the institutional integration of the country into the Western system, on the one hand, and the strong rejection of the West on the other', on the basis of the traditional ideology of right-left. The first actions for the country's integration into the West were its accession to the Organization for European Economic Cooperation (ECOE), the Council of Europe and NATO. However, membership in these institutions at that time was more of a strong attachment of the country to the western geopolitical area and less of an integration into the European system.

The cornerstone in this perspective for every country is the acceptance of the ideological and cultural rationale of the European Union. This was not the case with Greece, that is, there was no social desire, but rather it was imposed by the leading charisma (Constantine Karamanlis's statement: 'I have to throw the Greeks into the sea to learn to swim'), which resulted in Greece, the phenomenon of Europeanisation has to take on an 'asynchronous' character' (Ioakeimidis 2007). In other words, there was no uniformity and symmetry in the implementation of the process of Europeanisation.

The different degree of familiarity-assimilation was another 'division' between the representatives of the Greek political-party system and the levels of Greek society, according to what one looks for in the process of Europeanization. However, as a vision and political project, efforts to europeanise the image of the country took place during the rule of Prime Minister K. Simitis. The governments of this period attempted to bridge the gap between the former populist rhetoric and the imperatives stemming from the country's participation in the European Union.

Apart from any objections concerning the scope of the necessary reformist sectors that have been attempted or left vacant, the country's accession to the Economic and Monetary Union and its integration into the core of the Union ('the Schengen Area') and in its activities as a whole Common European Security and Defense Policy (ESDP) are considered top results of the policy goals set.

b) The idea that Greece is the 'center of the world', is based not only on the classical ancient Greek tradition and on the appearance of the Great Idea, in the later years, but also on its burial due to the Asia Minor Catastrophe and the emergence of ethnocentric perceptions that were mutated by the dictatorships Metaxa and the colonels. In the period after the coup, the state regime and the restoration of democracy, ethnocentric tendencies - with a strong religious element - still remain and occur depending on time and context, whilst taking the form of an anti-European and defense ethnocentrism. 
The former focuses on the rejection of the European Union with populist, nationalistic and religious discourses, fueling an 'underdog culture', while the latter rejects dialogue as a tool for resolving disputes and focuses on military power as the only instrument of enforcement, which further adopts a conspiratorial view of the international environment, actors and organizations.

c) Greece as a 'dependent, subordinate country' draws its content from the historical course of the Modern Greek state, the regime of protection from the Great Powers, the foreign interventions, the royal dynasty and, over the past 50 years, the role of the US in its interior affairs. This stereotype or otherwise syndrome gradually subsides with the country's integration into the European family.

d) Greece, as a 'poor, weak country', is understood in this way, due to the country's wealth capacity, a perception which cannot justifythe fact that Greece is in the 25 most developed countries internationally, in the EU and EMU. Such achievements eliminate this fatalistic view of the image and position of the country (Ioakeimidis 2007).

In the fundamental question of the catalytic impact of the process of Europeanisation of the Greek political system, the economy and in general the structures of the state, identity and culture, the useful conclusions drawn are the following (Ioakeimidis 2007): 1. the consolidation through the participation in the political system of the EU and the corresponding democratization of structures and political culture (strengthening the state interests), the autonomy and transparency of social institutions and the emergence of a democratic civil society.

Above all, however, participation in the EU process entails the externalization of the foreign policy, stemming from the weakening of the distinction between internal and external policy. 2. strengthening external security whilst increasing the negotiating power as a member state of the EU and engaging with wider issues of the international agenda and especially in its relations with Turkey. 3. the promotion of economic development - where significant transfers of resources are observed -, the EMU, the Community Support Frameworks for the improvement of the indicators of the Greek economy.

The upgrading of the international role, where besides the definitive resolution of existential questions about the identity and position of the Greek state in the international system, the challenge is now based on the fact that Greece has crossed the threshold of an 'integrationist country', and seeks even bigger achievements in the process of European integration and transformation of the EU. (as a federal system based on the 'integration model' and focusing on supranational integration institutions).

\subsection{Regime Change (Metapolitefsi) as a Dead-End Case Study and the Role of Leadership}

Observing the Greek state, after the coup and the state regime in 1974, we see the emergence of new trends that differentiate its previous course, with regard to the triptych: a system of Greek foreign policy, the means of exercising it and the 'emerging agenda' (Arvanitopoulos K. and Koppa M., 2005).

The first of these trends in the corresponding framework of analysis is the declining (mitigated) effect of internal political confrontations and the partial - specific consensus on the handling of external issues. This is explained by the possibility offered by the political system to the left-wing, but also, even for a short period, parties of the Communist Left, to take part in the country's governance and to pursue foreign policy by making it, to a certain extent, more flexible to the specificities of the international environment.

The next component underlying the Greek foreign policy is its European orientation, through its participation in the European Union's mechanism. Nevertheless, while the issue is nothing but being able to act and not the inertia in decision-making in European and international affairs, the delicate balance between the autonomous national-public policy as it is formed ad hoc by the respective leadership remains and here it is crucial to investigate the role of individuals and, on the other hand, to comply with the 'Brussels' requirements.

Here, as well, 'the weakening of national strategy shaping will only be a problem if there are serious differences between national choices and those of the majority of EU members' (Arvanitopoulos K and Koppa M., 2005). 
The other trend that reformed Greek politics after entering the EEC was to bring the economic dimension at the expense of the purely political aspects of participation in the European family. Such targeting, under the burden of globalization, through the achievement of Greece's participation in Economic and Monetary Union (irrespective of the method and its consequences) is instigated in the transformation of the Greek state into one, mutatis mutandis, of a 'mild power' size, compared to the military power of the 'neighboring country'. Something that the 2009 financial crisis extinguished, as it will be seen.

And if all these are the secondary proposals, the main proposal, which is based on the wisdom of Greek foreign policy, is the 'Europeanisation' of its objectives (as we will see in detail later). Helsinki and smoothing the way for Cyprus to join the EU and the 'road map' for Turkey's candidacy with those parameters that are of great importance for the Greek side (normalization of border disputes and appeals to the Hague Court)are compatible with this spirit (which involves the PASOK governments and especially the governments of Prime Minister K. Simitis).

The exercise of the EU presidency, the consequences of the rejection of the 'Annan plan' by the Greek-Cypriot side, the successful organization of the Olympic Games, the Greek position that 'Cyprus decides, Greece is in favor' and especially the remission and not the compression of time against Turkey (by the then New Democracy government, 2004) as regards the exhaustion of Helsinki's negotiating derivatives, is the ground on which Greek foreign policy is moving during this period.

The Greek Cypriot, inter-Balkan cooperation, the diptych of relations between Greece and the US and Euro-Atlantic relations, the Greek policy towards the Middle East and, above all, the Greek-Turkish relations constitute the axes or challenges of Greek foreign policy. A holistic and special commonality is the deposition of Greek hopes in the EU and the belief that encouraging Turkey on its European path will bring about the normalization of relations between the two countries. Since 1974, the governments of Karamanlis, Papandreou, Mitsotakis and Simitis have been facing an asymmetrical relationship with their neighbor as the main defensive problem of Greece.

The relationship remains asymmetrical as it concerns two countries that are at different developmental stages, sizes and strategic importance. The post-Cold War era has exacerbated the ethnocentric tendency of the Turks, while Greece has gone into the supranational logic of European concerns. 'Every Greco-Turkish crisis brings our country back into an antivistory past' (Veremis Th., 2005). For Greece, the belief that Turkey's shift to Europe would make Greek-Turkish relations more symmetric, has restored the European climate in Greek foreign policy.

Observing the means of exercising Greek foreign policy, we can see that the level of bilateral and multilateral diplomacy and the survival of the political culture of international organizations, particularly in NATO and the UN, in which Greece takes part, is a very crucial factor. More specifically, regarding the United Nations and the role of Greece, we can see that for Greece, the UN was the forum for defending and promoting national issues. In media res, policy-making and the exercise of multilateral and bilateral diplomacy, from the Greek side, draws its meaning from internal and systemic reasons(Zeppos K., 2005; Arvanitopoulos K. andKoppa M., 2005).

Balancing between the implementation of political principles within the UN framework and the promotion - through over-voting or abstaining in relevant decisions - of the bilateral relations between Greece and the Arab world, as well as the preservation of relations with NATO and the main objective of joining the European Community, was a duplicate of Greek foreign policy.

We saw 'Constantine Karamanlis' Polycentric Foreign Policy' and its continuation by A. Papandreou. 'Papandreou's policy attempted to interconnect principles such as popular sovereignty and national independence - principles that constituted elements of the pre-election PASOK program - with international parameters (Th. Kouloumpis (1987), 'Karamanlis - Papandreou: Leadership type and substance', in International Law and International Politics, issue 16, Thessaloniki, Observatory Publications, p.5-36).

Something that, as we saw, was launched by Konstantinos Karamanlis as he enabled and encouraged Greek foreign policy to reach beyond the West. The reconciliation and the allowance of the 'chamileonical' proclamation of the 'central' and 'distant', according to D. Constantas' analytical 
distinction, constitutes a 'realpolitik' approach by the governments of A. Papandreou before the end of the Cold War. Besides, such was the international systemic environment and the bipolar planetary scene, where such a set-aside was, more or less, permissible.

After 1989, the Greek governments, obeying the new reallocations in the structure of the international system, concurred both with initiatives within the UN framework and with the activation of the collective security mechanism in the Gulf War. Reading the international environment from a Greek perspective advocated invoking and adhering to principles and rules governing the operation of the international organization and providing a safer policy tool, albeit not always in line with the existing transnational order of things, which limits the ability the UN to play a determining role in the consolidation of international peace and security.

In a more liberal approach, the Greek governments, especially those of PASOK, under the leadership of K. Simitis, did not use the previous years' strategies, moving in minute limits regarding the developments in Yugoslavia, and considering the country's participation in the EU and penetration of both its identity and the relationship and image of Greece within the EU as a more privileged area to solve the Greek problems (Ioakeimidis 1998).

In the international law dimension (Rozakis Ch., 2005) and in its invocation as the other (the most important) means of exercising Greek foreign policy, we distinguish three periods:

a) 1974-1981, 'is the most fertile phase of the invocation and use of international law by Greece. Against Turkish revisionist attitudes, Greek foreign policy forms a compact body of arguments based on international law'. As noted by Chr. Rosakis (2005) what distinguishes at that time from the formation of the country's defense is the readiness of the Greek government to negotiate all matters with Turkey on the bilateral or international issues that are separating the two countries.

b) during the second period, 1981-1996, there is a more rigid approach with the removal of the 'loophole' on the national issues of the bilateral negotiation line, since the negotiation presupposes the existence of claims by both parties and not only by one, which can lead to mutual compromises.

The holistically realistic attitude of PASOK governments (and its ideological inheritance) cannot be 'considered to be particularly effective because the absence of dialogue, especially during a period of drastic development in the Law of the Sea on matters related to the Greek-Turkish pending issues (the new legal status of the territorial sea which allows expansion to $12 \mathrm{~nm}$ and the International Court's new tendencies in the delineation of the continental shelf based on the principle of equity), contributes to a compression of the pending, potentially volatile outcomes as the crises of 1987 and Imia (1996)made it obvious.

c) in the third period, 1996-2004, the Greek foreign policy was guided by the need to shift the focus of the Greek-Turkish and Cypriot issues to a new level, within the European Union.

Consequently, the acceptance of the release of 'Turkey's European course from Greek interference' and the Turkish candidacy, 'Turkey's recognition of the legal nature of the dispute over the continental shelf and the possibility of appeal to The Hague, as well as the readiness of the Greek side to accept bilateral negotiations as a step at least to resolve the dispute', predispose a more adaptable and flexible proposition to the Greek side (Rozakis ibid).

The concept of power over international law and defense policy, as parameters in the exercise of Greek foreign policy, implies their own distinct gravity. Proponents of the pragmatic model of international relations claim that 'power is the main element of politics', while 'international law and collective security systems have emerged to protect national-state distributive justice systems and not to undermine the legalistic devices of global governance that penetrate them because it serves some ephemeral hegemonic interests and fascist Darwinist theorems' (Ifestos, 2005). On the other hand, the foundation of the Greek defense policy is balancing Turkey and securing its national security through preventive strategy (Platias, 2005).

In the Cold War era, Greek defense policy 'was largely determined by the country's bilateral and multilateral obligations', while the Greek armed forces' mission was based on the US assessment that 'Greece's main security problem was of internal (communist danger) and not of external nature'.

The period after the coup and the state regime (1974)and then, the tragic experience of Cyprus radically altered the physiognomy of Greek defense policy on the basis of its own forces, a 'strategy 
of internal balancing' instead of allied aid, ie 'external balancing strategy', under the central defensive doctrine of deterrence.

Continuing the analysis in the field of the internal environment, it is obvious that the use of the individual level (see K. Waltz) is particularly applicable, and because of the Greek political system, decision moves towards the ceiling of the executive function. Then, the leader resorts to all his established philosophical and operational beliefs in his attempt to make a political decision, since his system of values is the only fixed point of reference in a rapidly changing, objective landscape. But most importantly, the code of conduct of a leader has greater interpretative and analytical value when it comes to decisions made in times of crisis rather than on programming initiatives (Ioakeimidis 2003).

The historical reference to crisis situations states that charismatic leaders 'sweep along structural and institutional variables on the basis of the application of their philosophical and functional political beliefs' (Arvanitopoulos 2005). In addition, as far as the crises of the post-revolutionary period are concerned, we are able to diagnose, on the one hand, the primacy of the gift of the founding leaders of the two major parties of power, and, on the other hand, the later and more recent questioning of the leader- due to interparty frictions and aspirations. In both cases, the relevant institutional functions are either scaled or flown, under the expense of political feasibility and necessity.

\section{THE EFFECT OF EUROPEANISATION}

The approach of Europeanisation goes beyond the orientation of classical integration theories at European level by shifting the attention mainly to the internal level and especially to the administrative adjustment of the member states via their accession to the Union (see Rometsch and Wessels 1996, Meny 1996, Hanf and Soetendorp 1998, Kassim 2000, Zeff and Pirro 2001).

As for the demarcation of Europeanisation, although some scholars have highlighted the relevance of the construction and diffusion of EU institutions and policies (see Borzel 2003b Radaelli 2003), most converge in understanding Europeanization as an adaptive process caused by European regional integration and an internal adaptation to European regional integration (Graziano P., Vink MP, (ed) 2007).

In particular, this term means the internalization of the political and organizational dynamics of the European Union 'in the organizational logic, system and structures of a national policy and in the process of policy formulation' (Ioakeimidis 2007). Detecting the penetration of Europeanisation into a number of areas of public policy reflects its varying degree of adherence. Its effect can be perceived in three dimensions:

- public policy,

- partial policy actions;

- political systems.

Observing the foreign policy of the Member States in connection with the phenomenon of Europeanization, we see that the concept of Europeanisation is very recent in the study of the internal impact of European regional integration, particularly with regard to the dimension of the Common Foreign and Security Policy (CFSP) in national foreign policies. It should be stressed that the two methods of integration / completion are still present after the Treaty of Lisbon, namely:

- The Community method of unification as an advanced system of law-making and dispute resolution - control

- The intergovernmental method of the CFSP, as a different system of law-making, where the role of the Court is incomplete, which cannot exercise control, while the will of the states hinders the political union.

And it is characteristic that the less acceptable on politicization the field of collective action is, the easier it is to cooperate. This is because, as we approach 'high politics', we encounter difficulties, and the explanation for this is that they are, as it will become evident later, the last battles of national sovereignty. 
The dominant Greek position and target of Greek foreign policy lies on the development of the Common Foreign and Security Policy of the Union (CFSP) and the European Security and Defense Policy (ESDP).

Greece, in particular, aims at developing a European defense and defense policy complementary to NATO in order for the Union to be able to protect the independence and territorial integrity of its member states. In this context, Greece has recommended introducing the concepts of 'external borders' and (territorial) integrity (Treaty of Amsterdam). For Greece, 'common defense should be based on the principle of the mutual assistance clause, giving the Union the character of the collective security system' (Kouveliotis, 2002).

With regard to Greek-Turkish relations, Greece lifted its earlier negative attitude towards Turkey and adopted Turkey's policy of 'controlled engagement' in the process of European unification as a prerequisite for its Europeanisation.

It should be taken into consideration that Turkey's Europeanization serves not only Greece's wider interests, but also southeastern Europe's and Europe's as a whole. Thus, Greece has supported Turkey's proclamation of 'a candidate for EU membership', a membership which will take place once the latter meets the criteria and conditions ('Copenhagen criteria', etc.), that is, as soon as it proceeds the process of Europeanisation (democratization) of its political, economic and social system.

This policy was reflected in the decisions of the Helsinki European Council (December 1999). These decisions also include arrangements for resolving cross-border problems as well as for unblocking Cyprus' accession to the EU after having managed to achieve a settlement of the political problem of Cyprus. With Helsinki's decisions, Greece succeeded in putting Turkey in the process of Europeanisation but at the same time making relations and problems with this country an issue for the European agenda (Ioakimidis P.K., (2003), and see YavasGokcen, (2007).

The Europeanization of Greek foreign policy reflects a certain change in style, rather than the content that is always the same and indiscriminate, as a shift to security issues to an EU level. At the same time, Greece transposed the EU policy of reconciliation and peaceful coexistence with its neighbors in the transnational field of relations with Turkey, narrowing the spectrum of these relations and differences to Euro-Turkish content (a corresponding approach followed, as we will see in the case of the accession of Cyprus to the EU).

In November 1999, the Greek Government presented to the Finnish Presidency a memorandum on the Greek attitude towards Turkish candidacy. Firstly, it was argued that non-resolving the Cyprus problem should not be a hindrance to the European perspective of the country, and secondly it was stressed that each candidate country should accept the jurisdiction of the International Court of Justice and that Turkey should be given precise guidelines as for the rights and duties that are prerequisites for the candidate Member States.

And finally, following Helsinki's decisions, the Greek memorandum was accepted and the Greek positions were adopted, in such a way that the Greek-Turkish problems were transformed into issues pertaining to Euro-Turkish relations. Through this policy and not with the earlier inelastic approach, Greece presented a more sophisticated and European presence in resolving its differences, from which it benefited more than in the past.

This kind of Europeanization of Greek foreign policy reflects the adoption of the corresponding political actions and the corresponding abandonment of others that were more entrenched and ineffective. On this basis, the ongoing change, after the accession - the Europeanization of the foreign policy of the Greek state, 'is grouped into four major categories (Ioakeimidis 2007):

- The agenda of the Greek foreign policy', which, without deviating from the one-dimensional but insurmountable way of supporting the so-called national positions, is now enriched by means and objectives, as participation in the European Union is bound to the issues related to it and escape the narrow geographical boundaries and political themes that traditionally characterized the Greek foreign policy. Mainly it is understood that Greek foreign policy 'plays in a different terrain', alongside that of NATO or the UN. 
This is directly related to the emergence of a corresponding political culture that considers the Union to be a privileged field of action, both for the classical Greek interest issues and the news that comes from entering the European family. This new concept and culture and the process of its formation are inextricably linked to the unifying phenomenon and the course of Europeanisation.

- The change of the respective organizational structures of foreign policy exercised by the Greek state.

The radical restructuring of the Ministry of Foreign Affairs (Passas, 2005) illustrates this new reality, as new thematic issues of European interest raise the existence / origin of corresponding schemes with regard to the function of the Greek state. Even more, when participation in the Union renders difficult, the traditional distinction between internal and external policy imposes a more European character on all Ministries and on the pursuit of public policy.

Above all, however, the Europeanization of Greek foreign policy poses a 'nuclear issue' in the pursuit of foreign policy, as we have seen in the previous chapter. This is no other than the dipole of leadership / personality and institutional processes, i.e the institutionalization process and the predominant role of the institutions, not of the person.

Thus, the consequence of Europeanisation is the emergence of structures and processes that are in charge of this orientation, and the role of the person who, after the initial omnipotence that has to do with the choice (accession to the EU), is no longer required to be on the front of the processes, which follow their own function and stand out.

- Strengthening the negotiating power / power as a result of EU membership, which as a new factor differentiates itself in improving the position of the country in the regional and international environment.

- The 'constraints' in the policy exercise.

The significance of this parameter lies precisely on the disengagement of Greek foreign policy from dogmas and conceptual shapes in the form of anchorages which have embedded it into short-sighted policies.

Moreover, it is well known that such a carefully planned design from the Greek side in synergy with the Republic of Cyprus has also brought Cyprus's entry into the European Union. For Greek foreign policy and the view of the consolidation process, sine qua non is the diptych of deepening the unification and the process of enlargement of the Union (Turkey and the Western Balkan countries).

\section{COMPARATIVE ANALYSIS: THE EXAMPLE OF ISRAEL}

According to Alastair Iain Johnston, strategic culture isa system of symbols (e.g., argumentation structures, languages, analogies, metaphors) which acts to establish pervasive and longlasting strategic preferences by formulating concepts of the role and efficacy of military force in interstate political affairs, and by clothing these conceptions with such an aura of factuality that the strategic preferences seem uniquely realistic and efficacious" (RafałKopeć, 2016). What is more 'shared beliefs, assumptions, and modes of behavior derived from common experiences and accepted narratives (both oral and written), that shape collective identity and relationships to other groups, and which determine appropriate ends and means for achieving security objectives' (G. F. Giles, 2002).

In general terms, the geopolitical background of Israel's strategic culture is largely determined by geopolitics of the Middle East. For this country the view at the issues of the international environment is in the spirit of Hobbes, based on the principle that each of its participants may rely primarily, or even exclusively, on himself. Strategic doctrine sees the reality according to the state of war or peace and not something else. The army is a central institution of the state and society, to the extent that it has led to the production of informal civil-military network dominating the sphere of national (RafałKopeć, 2016). As we can see, the basic assumption is that there is the need to maintain absolute military superiority in the region and self-defense. 'The system of symbols shaping this culture partly extends until the times of the Bible. Israel has cultivated - some would say imposed - a set of beliefs and assumptions on its citizenry as a means of simultaneously building and defending the fledgling Jewish state in the face of deep Islamic hostility. This belief system is rooted, in part, in such ancient texts as the Bible but is under considerable pressure from contemporary demographic, ideological, 
and religious changes in Israeli society. As a result, there is both continuity and change in what passes for "appropriate" ends and means of achieving security in Israeli terms. Indeed, the strategic culture framework could provide a useful tool for anticipating how the Jewish state might come to grips with its ongoing internal, as well as external, security challenges(G. F. Giles, 2002).One of key symbols is the image of the Jewish people as a source of persecution' (RafałKopeć, 2016).

The constructivistic point of view is dominant regarding the debate of political and strategic culture. Israel's example points out this dimension due to the fact that considering the shape of its strategic culture, we should take into account both the geopolitical factors, and the nature of Israeli society.

\section{The Fiscal Crisis and its Consequences for the Political Culture and the COUNTRY'S STRATEGIC ORIENTATION}

The Eurozone crisis, which occurred after the 2008 financial crisis, is a multifaceted policy problem, with the collapse of financial institutions in the USA in 2008 as its main reason. Initially, the development of the Monetary Union did not occur alongside a Bank Union, that is, both the regulation and rescue of the banks lied solely on the responsibility of national states. Therefore, 'the 2008 financial crisis sparked not only a banking crisis but also a sovereign debt crisis, as governments in several Eurozone countries struggled to find the funds to rescue their insolvent banks' (Glencross, pp. 285-309). For Eurozone countries such as Greece, Ireland, Portugal, and Cyprus finding markets to lend them such amounts of money remained in the sphere of their imagination. Thus, the options presented to them were either to receive an emergency funding or to withdraw from the euro. Since the latter was out of the question, austerity, cost cut and reduction of salaries were a one-way direction, which came after Germany's decision to impose strict measures to the aforementioned states. These sine qua non conditions were the first step towards the establishment of a permanent bailout mechanism, through the redesign of the EU treaties. The crucial step towards this direction was through changes in the operation of the European Central Bank (ECB) and 'gradual progress toward an eventual EU banking union' (Glencross, pp. 285-309).

For Greece, years of unrestrained spending, cheap lending and a failure to implement financial and administrative reforms left this European country badly exposed when the global economic crisis struck (Papanastasopoulos, 2017).On June 27, 2015, Greek Prime Minister Alexis Tsipras announced a referendum on austerity measures, after a whole semester of 'Sisyphean and dead end' negotiations and ideological obsessions. Then he came down to earth (we must not forget his despairing journey to Russia and the economic damage due to this uncertainty) (Papanastasopoulos, 2017). On September 20, 2015, Greek Prime Minister Alexis Tsipras and the Syriza party 'won a snap election', which gave them the mandate to continue to press for debt relief in negotiations with the EU, with the price to continue with the unpopular reforms promised to the EU (Papanastasopoulos, 2017).

As can be seen, the regressions of Greek society in the face of the shock that wages and pensions have suffered because of the memorandums were intense. No other people have treated such a steep transition from the euphoria to depression. The political culture that has emerged has the characteristics of commitment to new data and to the rescue packages.

And this is something that is credited to Greek citizens, as more or less pragmatic statements of competent officials at home and abroad indicate. But the image of the country abroad was tarnished, as the Greeks were identified as a wasteful and lazy people. The responsibility of the political executives who, in order to rise to power, did not hesitate to accuse an entire people of exclusivity, and its mentality is something that no historian of the future can ignore. So the country lost valuable diplomatic and political capital that had been so successful since its entry into the European family.

They are, in fact, tragic ironic states new to democracy and the European capacity to mistreat Greece and become honorable to reality (the opposite view would say that they have given their weight to the packages of the Greek rescue). Regarding the country's strategic orientation, despite the whispers of Russia's help, the signing of the memorandum by the SYRIZA government and the trip of the Greek prime minister to the United States (2017) confirmed the stances of Greece's strategic orientation and foreign policy.

At the level of the strategic culture, the salary cuts for the Armed Forces executives and especially the equipment were one of the price paid by the country in terms of its national defense and security; all 
the more so as developments in the region are proving to be rapid and dangerous. The fronts in the Eastern Mediterranean and the Middle East have clearly influenced the form of the refugee, especially the Greek state, which, as anybody says, is an islet of stability in an area of instability. And it has to face Turkey that more than ever is no longer a rude, but a dangerous and aggressive neighbor.

Above all, in terms of strategic culture, for a society such as the Greek that is experiencing existential problems, the prism with which it sees every threat embraces everyday life and survival. External threats have been replaced by existential threats. And this is more serious than anything else. Fitting political and strategic culture with materials that do not give coherence and sense of ability to manage threats, but simply obedience and retreat in the face of need.

We simply live the present and as a slave to the checks of the state borrowers we bent our head against the most 'strong and uncontrolled' Turkey; and to the parliamentary dictatorship. In social terms, injuring the bourgeoisie, through relentless taxation and the crash of entrepreneurship, implies its own consequences. Apart from any ideological interpretation, the bourgeoisie is, in every state and especially in Greece, a catalyst for developments and a guardian of political and strategic culture. But its impoverishment weakens the political and strategic culture with consequences for the future. And this is something that must concern both the ordinary and the Greek citizens themselves. The physiognomy of a society and the way it sees its threats requires trust and, above all, respect for the terms of the 'social contract'. Remembering Carl Schmidt, if these terms are not met then the 'enemy is in and out'.

\section{THOUGHTS AND CONCLUSIONS}

The cleavage of political and strategic culture in the Greek political and strategic culture after the coup and the state regime (1974) is more than visible and it seems as the 'Danaides Myth'. In parallel, the detection of the case of Israel, according to any analogy, demonstrates this judgment.

For Greek strategic culture, challenges are always there either in the Aegean, in Cyprus as waves of illegal immigration, or finally as risks to regional stability and energy security. The crucial 'primate' remains or accumulates in other forms, which are expected to explode as crises at a national or even a wider level (Ntokos, 2005).

Such a reality requires the continued readiness of the modern Greek state and its external policy. An ability to interpret international developments and deal with all sorts of crises. This arsenal will be on the one hand recognition of the geopolitical factor and on the other hand economic and military sufficiency, institutional, educational and social capital and, above all, consensus on major national goals. In other words, the oxygenation and feedback of the dialectical relationship between political and strategic culture, much more after the return of the country to regularity and the end of the memorandums.

Such a necessary claim and targeting passes through the institutional and constitutional reform and enrichment of Greek foreign policy. To this end, weighing the external environment and internal conditions is a critical methodological tool. Words, names, symbols seem to take a near-supernatural significance for us, and they take us away from reality which ipso facto governs as a distortion the visual aspect of Greek foreign policy and the reflection of political and strategic culture (Tsoukalis, 2005).

The 'fronts' are open and delimited either with respect to:

- The war on terrorism, 'asymmetric threats' and trade in conventional or nuclear weapons,

- The crises in the Balkans, the Middle East and the formed political context in the light of relations with the Arab world and Israel,

- The attempts to establish borders, institutional and economic reconstruction of areas that have just been independent or terminated by their civil conflicts (in the area of traditional and Euro-Asian Balkans)

- The future of Kosovo, the former Yugoslav Republic of Macedonia, Albania and the reemergence of Serbia on the international scene,

- The energy game in the region and the position of the Republic of Cyprus. 
- The Greek-Turkish relations, where the situation, without fears, is more than dangerous.

Therefore, the analysis of the geopolitical and geostrategic setting of the wider Mediterranean region is drawn up on the three-dimensional level:

(a) politics, b) the economy and c) security (Lesser I., Larabee F. S., Zanini M., Dengler K.V., Ceridis D (eds.) (2003).

In the first dimension, what needs to be supervised rather than refractory is the relations and the balances that are shaped in the wider Balkan region and the Middle East. Primarily, the play of playerstates on the Euro-Asian chessboard (Brzezinski Z., (1998), can not and must not escape the analytical glance of the Greek side.

Undeniably, therefore, the station of disengagement from ideological attachments and deadlocks, without this being a deduction or distortion from fixed values, gives the new stigma of the course to be followed. A course in which adherence to an idealist framework guided by international law, although it is a fundamental position of a country that respects principles and rules, but the tension with which the Greek side interprets this position mitigates the high national strategic planning, making the country's reactions predictable and trapped. And this is a parameter that deserves particular attention.

Such a function should take into account the American side's perception of the wider region, where Greece and Turkey are allies of the United States. To this end, US policy towards the two countries can not be dealt with through a framework of bilateral relations, but it can and must be addressed through a context of interdependence that refers to issues that go beyond narrow geographical boundaries. The prime of this is to strengthen its commercial and military power and maintain its geostrategic value at sea in relation to the Atlantic (mainly) and European geopolitical aspirations in Eurasia as sine qua non strategic prerequisites.

The salience of political culture, as manners of administrative capacity and (international) political gravity, especially for smaller countries, is the cornerstone of strategic culture and readiness to address any challenges, both internal and external.

\section{REFERENCES}

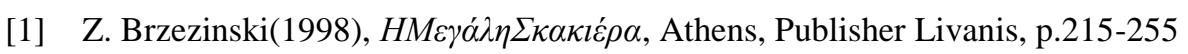

[2] K. Featherstone(2005) (ed), The Challenge of Modernization: Politics and Policy in Greece, West European Politics, V.28 2

[3] K. Featherstone and G. Kazamias(2001), Introduction: Southern Europe and the process of "Europeanization", in Featherstone K., and Kazamias G., (eds), 'Europeanisation and the Southern Periphery', London: Frank Cass

[4] K. Featherstone - K. Ifantis, (1996) (ed), Greece in Changing Europe: Between European Integration and Balkan Disintegration? Manchester: Manchester University Press

[5] G. F. Files (2000),Continuity and Change in Israel's Strategic Culture, Prepared for Defense Threat Reduction Agency Advanced Systems and Concepts Office

[6] M. Furlan (2017),Strategic Culture and Strategic Behavior in the State of Israel, Working Paper, March 2017, DOI 10.13140/RG.2.2.26382.97603

[7] YavasGokcen(2007), 'The Europeanization of the Aegean Dispute between Turkey and Greece: a constructivist/ discursive approach', International Studies Association 48th Annual Convention, Chicago, Feb 28

[8] P. Graziano\& M. Vink. (2008), Europeanization, New Research Agendas, Publisher: Palgrave Macmillan UK

[9] Johnston (1995), Thinking about Strategic Culture,International Security, Volume 19, Number 14, Spring 1995, pp. 32-64

[10] P.C. Ioakimidis(2001), The Europeanization of Greece: An Overall Assessment, Featherstone K.,Kazamias G., (ed), Europeanization and the Southern Periphery, London: Frank Cass

[11] R. Kopec (2016), The Determinants of the Israeli Strategic Culture, PrzegladNarodowosciowy - Review of Nationalities Jews $\mathrm{nr}$ 6/2016 (on line)

[12] Th. Kouloumpis (1987), 'Karamanlis - Papandreou: Leadership type and substance', in International Law and International Politics, issue 16, Thessaloniki, Observatory Publications, p.5-36. 
'Danaides Myth' in Greek Political and Strategic Culture after the Coup and the State Regime (Metapolitefsi) (1974)

[13] K. Kouveliotis(2002), The Europeanization of Greece's Foreign and Security Policy, University of Aberdeen, Publisher Paraskinio

[14] O. Lanza\& K. A. Lavdas (2000), The disentanglement of interest politics: Business associability, the parties and policy in Italy and Greece,European Journal of Political Research 37: 203-235, Kluwer Academic Publishers. Netherlands

[15] J. S. Lantis (2002),Strategic Culture: From Clausewitz to Constructivism, Prepared for Defense Threat Reduction Agency Advanced Systems and Concepts Office

[16] K. A. Lavdas (2000), Reconceptualizing Politics: Concepts of Politics in Modern Greek Political Culture, ECPR Joint Sessions, 'The History of Political Concepts: A New Perspective on European Political Cultures, Copenhagen

[17] K. A., Lavdas (1997), The Europeanization of Greece, Interests, Politics and Crisis of Integration, London, MacMillan G. Rose, Neoclassical Realism and Theories of Foreign Policy,1998, World Politics, Vol 51, No 1 (Oct 1998) p. 144-172), Cambridge University Press

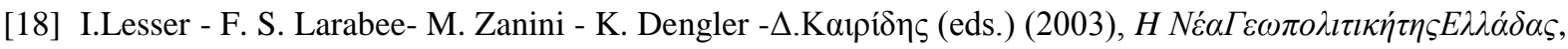
Athens: Publisher I. Sideris, p.49-95

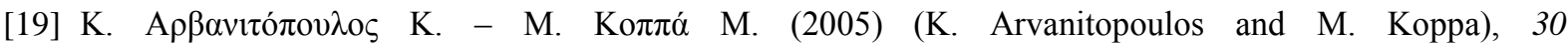

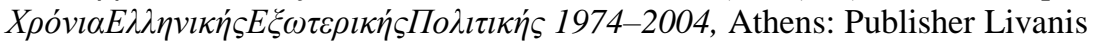

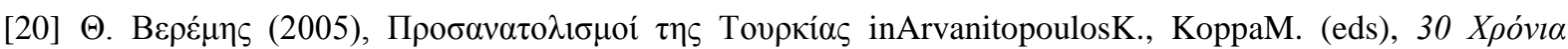

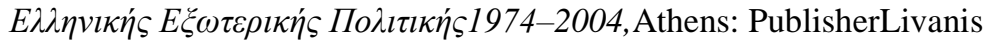

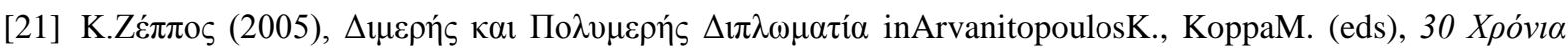

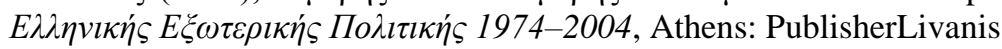

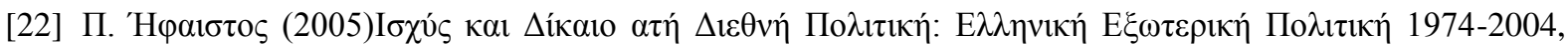

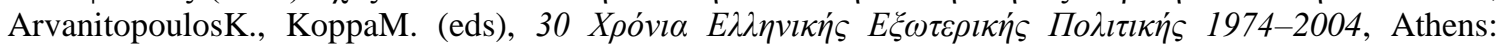
PublisherLivanis

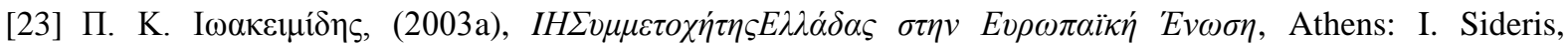
Publisherp.537-564.

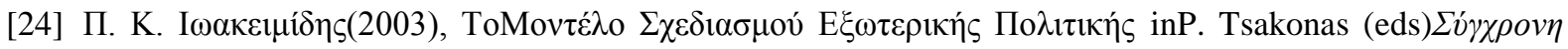

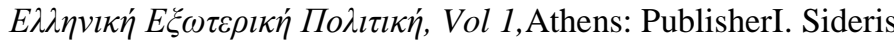

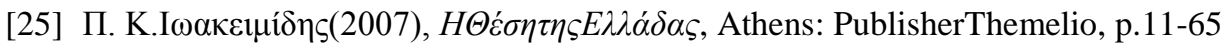

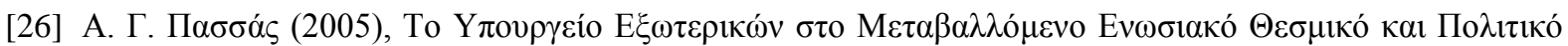

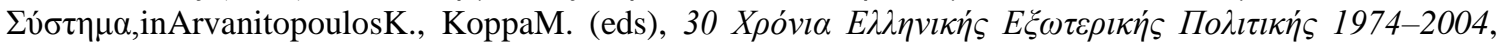
Athens: PublisherLivanis

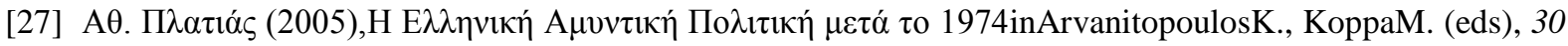

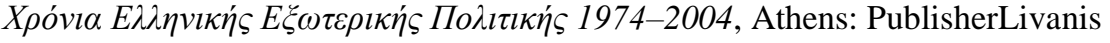

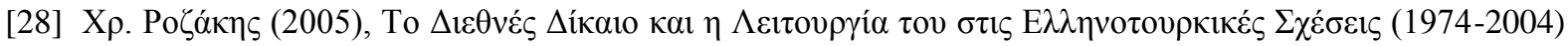

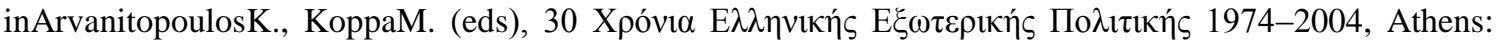
PublisherLivanis

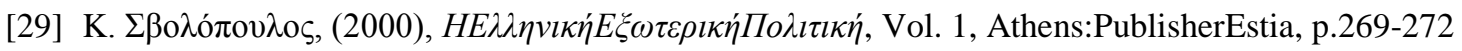

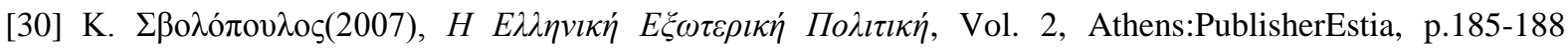
\&p.190-201

Citation: Nicolas Papanastasopoulos. “'Danaides Myth' in Greek Political and Strategic Culture after the Coup and the State Regime (Metapolitefsi) (1974)". International Journal of Political Science (IJPS), vol 4, no.2, 2018, pp.27-40. doi:http://dx.doi.org/10.20431/2454-9452.0402003.

Copyright: (c) 2018 Authors. This is an open-access article distributed under the terms of the Creative Commons Attribution License, which permits unrestricted use, distribution, and reproduction in any medium, provided the original author and source are credited. 